\title{
PROGRAM PENGABDIAN MASYARAKAT PENCEGAHAN PERILAKU SEKS MENYIMPANG (LESBI, GAY, BISEKSUAL DAN TRANSGENDER/LGBT) \\ DI SMA NEGRI 2 SINGAPARNA
}

\author{
Santi Susanti, S.SiT, M.Kes \\ Email : santiazhari@gmail.com
}

STIKes Respati

\section{A. DASAR PEMIKIRAN}

Perilaku seksual yang menyimpang masih merupakan hal yang tabu bagi masyarakat Indonesia yang berbudaya ketimuran, masyarakat masih kental dan memegang teguh apa yang dinamakan dengan ajaran moral, etika, dan agama, sehingga perilaku seksual yang menyimpang tentu bukanlah fenomena yang dapat diterima begitu saja. Perilaku seksual yang menyimpang itu sendiri, muncul atas dasar orientasi seksual yang menyimpang. Orientasi seksual adalah kecenderungan seseorang untuk mengarahkan rasa ketertarikan, romantisme, emosional, dan seksualnya kepada pria, wanita, atau kombinasi keduanya (Douglas, Markus, 2015). Perilaku seksual meyimpang dilakukan oleh kelompok- kelompok orang yang memiliki orientasi seksual menyimpang, atau lebih dikenal dengan istilah kelompok LGBT (Lesbian, Gay, Bisexual, dan Transgender/Transsexual). Indonesia adalah negara yang berke-Tuhanan, sebagai negara yang mengakui adanya Tuhan, warga negaranya diberi kebebasan untuk melaksanakan perintah Tuhan sebagaimana yang termaktub dalam kitab suci dan ajaran agama masing-masing. Berdasarkan pada ajaran agama-agama yang diakui di Indonesia, tidak terdapat alasan pembenar yang dapat dijadikan dalil untuk membenarkan perilaku seksual menyimpang. Perkembangan jumlah homoseksual di Indonesia bertambah setiap tahunnya, termasuk di dalamnya orientasi seksual yang non heteroseksual

seperti, biseksual dan transgender. Data statistik menujukkan 8-10 juta populasi pria di

Indonesia pada suatu waktu terlibat pengalaman homoseksual dan sebagin masih aktif melakukannya.

Data demografi menunjukkan bahwa remaja merupakan populasi yang besar dari penduduk dunia, WHO (1995) sekitar seperlima dari penduduk dunia adalah remaja. Sekitar 900 juta berada di negara sedang berkembang. Di Indonesia menurut Biro Pusat Statistik (1999) kelompok remaja adalah sekitar $22 \%$ yang terdiri dari $50,9 \%$ remaja lakilaki dan $49,1 \%$ remaja perempuan (dikutip dari Nancy P, 2002). Masa remaja merupakan masa peralihan antara masa kanak-kanak dan masa dewasa, yang dimulai pada saat terjadinya kematangan seksual. Memasuki masa remaja yang diawali dengan terjadinya kematangan seksual, maka remaja akan dihadapkan pada keadaan yang memerlukan penyesuaian untuk dapat menerima perubahanperubahan yang terjadi. Kematangan seksual dan terjadinya perubahan bentuk tubuh sangat berpengaruh pada kehidupan kejiwaan remaja. Selain itu kematangan seksual juga mengakibatkan remaja mulai tertarik terhadap anatomi fisiologi tubuhnya. Selain tertarik kepada dirinya, juga mulai muncul 
perasaan tertarik kepada teman sebaya yang berlawanan jenis.

Dalam pencegahan perilaku seks menyimpang maka diperlukan program

\section{B. TUJUAN}

Tujuan program ini adalah meningkatkan pengetahuan remaja tentang perilaku seks menyimpang.

\section{SASARAN}

Sasaran ini adalah seluruh siswa kelas 10 sd 12 di SMA Negri 2 Singaparna pendekatan kepada remaja tentang LGBT sehingga meningkatkan pemahaman remaja akan hal tersebut. Oleh karena itu diperlukan program pengabdian masyarakat untuk sosialisasi tentang LGBT pada remaja di SMAN 2 Singaparna.

\section{TEMPAT DAN WAKTU}

Tempat pelaksanaan programdilaksanakan di SMAN 2 Singaparna.Waktu pelaksanaan adalah pada tanggal 3 Januari 2019.

\section{E. HASIL KEGIATAN}

Selama proses penyuluhan mendapatkan respon yang baik dari seluruh siswa. Para siswa aktif dalam sesi tanya jawab tentang LGBT. Untuk mencegah maraknya perilaku penyimpangan seksual berupa LGBT ini salah satu pendekatan yang diperlukan adalah pemberian edukasi pada remaja. Remaja yang berada pada rentang usia 13-21 tahun menurut Hurlock (1999) berada pada periode yang rentan. Terutama berkaitan dengan tugas perkembangannya yang merupakan periode transisi, dan masa pencarian identitas diri. Salah satu bentuk penyampaian informasi tentang seksualitas dapat diberikan dalam bentuk penyuluhan.

Dalam kajian Counseling and Mental Health Care of Transgender Adult and Loved One, fenomena transgender dinyatakan muncul tidak hanya karena pengaruh lingkungan. Pengaruh dari budaya, fisik, seks, psikososial, agama dan kesehatan juga turut andil dalam membentuk individu menjadi LGBT. Menurut Byrd, faktor genetik memang menjadi kontributor terbentuknya individu menjadi seorang lesbi, gay, biseksual atau transgender sebagaimana yang digarisbawahi oleh kaum LGBT. Namun demikian, bukan berarti otomatis membuatnya sebagai LGBT.

Pola asuh orang tua menjadi faktor terpenting dalam membentuk dan mewarnai sosok anak. Bandura mengatakan, lingkungan dapat dibentuk oleh perilaku dan sebaliknya perilaku dapat dibentuk oleh lingkungan. Dalam hubungan resiprokal ini terjadi pembelajaran sosial yang mengarah pada transfer informasi, kebiasaan atau perilaku. Anak yang selalu menonton tayangan perilaku tak laras gender seperti laki- laki yang berperilaku gemulai membuka peluang bagi anak untuk bersikap sama. Reaksi yang muncul pertama kali adalah perasaan aneh, lucu, atau bahkan tidak memberikan reaksi apapun, sebab anak belum memiliki skema pengetahuan tentang sosok maskulinitas pada laki-laki. Reaksi kedua, anak mulai memiliki 
bahwa laki-laki bersifat seperti apa yang dilihatnya. Reaksi ketiga anak mengikuti gaya atau perilaku laki-laki yang sering dilihatnya. Selanjutnya perasaan aneh atau lucu di awal reaksi berubah menjadi perasaan yang understandable dan acceptable. Dalam kondisi ini sudah terjadi internalisasi nilai tentang sosok laki-laki yang lama kelamaan sangat mungkin berubah menjadi internalisasi pola perilaku.

Jika lingkungan dapat mempengaruhi perilaku dan sebaliknya perilaku dapat dipengaruhi oleh lingkungan, maka saat mulai terjadi internalisasi nilai, individu dapat membatasi diri untuk bersikap lebih bijak dalam menyikapi fenomena LGBT. Individu dapat merubah persepsi sekaligus pola fikir yang bersimpul pada pola perilaku untuk menolak atau mengikuti suatu fenomena tertentu.

\section{F. LAMPIRAN}

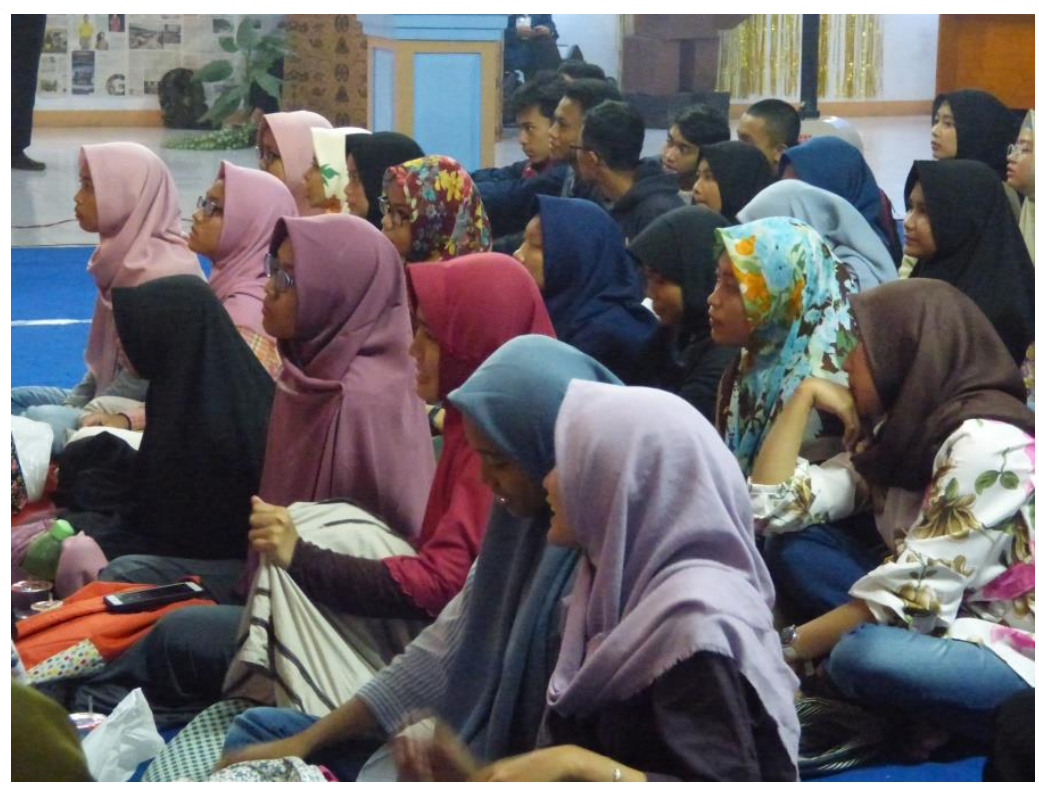

